\title{
DETECTABLE ANTI-DENGUE VIRUS IGM ANTIBODIES AMONG HEALTHY INDIVIDUALS IN OGBOMOSO, OYO STATE, NIGERIA
}

\author{
${ }^{1}$ Oladipo E.K., ${ }^{2}$ C. Amanetu, ${ }^{1}$ T.A. Gbadero and ${ }^{1}$ J.K. Oloke \\ ${ }^{1}$ Department of Pure and Applied Biology (Microbiology/Virology Unit), \\ ${ }^{2}$ Department of Science Laboratory Technology (Microbiology Unit), \\ LadokeAkintola University of Technology, P.M.B 4000, Ogbomoso, Nigeria
}

Received 2013-04-12; Revised 2013-07-16; Accepted 2014-02-15

\begin{abstract}
Dengue fever is a zoonosis maintained in nature by mosquitoes transmitting virus between non-human primate species, most of which develop clinically in apparent infection. It has been found to be endemic in Africa and beyond. A survey for Dengue virus IgM antibody was carried out in Ogbomoso (urban and rural areas) using Enzyme Linked Immunosorbent Assay (WKEA Med Supplies Corp, Dengue fever virus ELISA Kit (China), to determine the seroprevalence and true incidence of dengue virus in Ogbomoso. A total of 186 apparently healthy individuals were recruited into the study. The sera of 93 subjects who consented to participate were collected. The mean age of the subjects tested was $37.6 \pm 0.67$. Anti-Dengue virus IgM antibodies were found in 16/93, (17.2\%). The highest prevalence of anti-Dengue $28.6 \%$ was found in persons whose ages were between $0-15$ years, males $(18.9 \%)$, civil servants $(26.3 \%)$ and urban dwellers (21.3\%). The findings from this study show that there is primary infection of this virus in Ogbomoso and suggest the need for preventive and control measures against dengue fever virus.
\end{abstract}

Keywords: Dengue, Dengue Virus, IgM, Ogbomoso, ELISA

\section{INTRODUCTION}

Dengue fever is aglobally significant arthropod-borne viral disease infecting people annually. The virus belongs to the family Flaviviridaewhich contain non-segment, positive-stranded RNA genome of 10862 nucleotides with a 5' cap structure and a non-polyadenylated $3^{\prime}$ end. (Chamber et al., 1990). Dengue fever virus is primarily transmitted by Aedesaegypti (Weaver and Reisen, 2010). Dengue fever virus is maintained in nature in cycles that involve preferred blood-sucking vectors and vertebrate hosts (Gulber, 2010), the virus is maintained in the forests of Southeast Asia and Africa by transmission from female Aedes mosquitoes-of species other than Aedesaegypti-to her offspring and to lower primates. Dengue is an acute viral illness with clinical manifestations such as fever, arthralgia, myalgia, rash, headache and sometimes thrombocytopoaenia. The virus seems to have no detrimental effect on the mosquito, which remains infected for life.

Dengue fever is a zoonosis maintained in nature by mosquitoes transmitting virus between non-human primate species, most of which develop clinically inapparent infection. Dengue fever is likely underrecognized and under reported in Nigeria because of low awareness by health care providers. Dengue virus has been shown to be actively circulating in various parts of Nigeria (Dawurung et al., 2010; Baba and Talle, 2011).

It is useful to detect the $\operatorname{IgM}$ antibodies in the selected population to know the rate of recent infection. Therefore a sero-epidemiological study is required to determine the prevalence and true incidence of Dengue fever virus in Ogbomoso.

Corresponding Author: Oladipo E.K., Department of Pure and Applied Biology (Microbiology/Virology Unit), LadokeAkintola University of Technology, P.M.B 4000, Ogbomoso, Nigeria 


\section{MATERIALS AND METHODS}

\subsection{Study Site and Population}

The study sites were two settlements in Ogbomoso (Ayeedaade, an urban area in Ogbomoso North Local Government Area and Otamokun a rural settlement in OgoOluwa Local Government Area). Ayedaade is an urban settlement majority of the dwellers being literate having teachers, students, civil servants etc,among their population, while Otamokun, the rural setlement had majorly farmers, traders, artisans etc as their occupation.All consenting subjects were recruited consecutively. Subjects were asked to fill the structured questionnaires, which contain demographic information and history of previous vaccination to any flavivirus e.g., dengue, westnile and yellow fever.

\subsection{Sample Collection (Blood)}

Blood samples were collected in a tube without anticoagulant. A tourniquet was firmly tied to the upper arm of the donor while sitting and skin sterilized with $70 \%$ alcohol. The sterile needle was inserted into conspicuous antecubital vein and the plunger of the sterile syringe was withdrawn and pressure applied to the puncture site with a cotton wool to stop bleeding. Blood sample was spun on a bench centrifuge at $3,000 \mathrm{rpm}$ for $10 \mathrm{~min}$ to obtain serum. Serum was separated immediately.

\subsection{Laboratory Method and Analysis}

The consented 93 subjects' sera were tested for Dengue fever virus IgM by the Enzyme-Linked Immunosorbent Assay (ELISA) test. The Dengue fever virus specific IgM antibodies were studied by the commercial WKEA Med Supplies Corp, Dengue fever virus ELISA Kit (China), according to the manufacturer's instructions. All the specimens were analyzed using the enzyme immunoassay test. The presence or absence of dengue fever virus IgM was determined by comparing the sample absorbance with the absorbance of the cut-off calibrator. The data obtained were subjected to descriptive statistical analysis using SPSS version 17.0 (SPSS Inc Chicago, III, USA).

\section{RESULTS}

Out of 93 subjects whose sera were tested using ELISA, 16 (17.2\%) was positive for anti-Dengue IgM. The highest prevalence of anti-Dengue IgM6 (17.1\%) was found in persons whose ages were between $0-15$ years and the least was found in 46-60 years $3(15.0 \%)$ as shown in Table 1. Out of 37 males, $7(37.8 \%)$ were positive for anti-Dengue virus $\operatorname{IgM}$ while among the 56females, $9(16.1 \%)$ were positive for anti-Dengue virus IgM as shown in Table 2.

Among 19 civil servants, 5 (26.3\%) were positive for anti-Dengue virus IgM; Out of 18 students, 4 (22.2\%) were positive for anti-Dengue virus IgM; Out of 13 artisans, $2(15.4 \%)$ were positive for anti-Dengue virus IgM; Out of 22 who were traders, $1(6.3 \%)$ were positive for anti-Dengue virus IgMas shown in Table 3.

Considering the geographical distribution as shown in Table 4 out of 47 urban dwellers, 10 (21.3\%) were positive for anti-Dengue virus IgM while among 46 rural dwellers, $6(13.0 \%)$ were positive for antiDengue virus IgM.

Table 1. Age distribution of anti- dengue virus igmantibodies in ogbomosho

\begin{tabular}{lll}
\hline Age range & No tested & No with anti-dengue \\
\hline (Years) & $(\%)$ & Virus IgM $(\%)$ \\
$0-15$ & $7(7.5)$ & $2(28.6)$ \\
$16-30$ & $25(26.9)$ & $4(16.0)$ \\
$31-45$ & $35(37.6)$ & $6(17.1)$ \\
$46-60$ & $20(21.5)$ & $3(15.0)$ \\
$61-75$ & $6(6.45)$ & $1(16.7)$ \\
Total $(\%)$ & $93(100)$ & $16(17.2)$ \\
\hline
\end{tabular}

Table 2. Sex distribution of anti-dengue virus IgM antibodies in Ogbomoso

\begin{tabular}{lll}
\hline Sex & $\begin{array}{l}\text { No tested } \\
(\%)\end{array}$ & $\begin{array}{l}\text { No with anti- dengue } \\
\text { virus } \operatorname{IgM}(\%)\end{array}$ \\
\hline Female & $56(60.2)$ & $9(16.1)$ \\
Male & $37(37.8)$ & $7(18.9)$ \\
Total $(\%)$ & $93(100)$ & $16(17.2)$ \\
\hline
\end{tabular}

Table 3. Occupational distribution of anti-dengue virus IgM antibodies in Ogbomoso

\begin{tabular}{lll}
\hline Occupation & $\begin{array}{l}\text { No tested } \\
(\%)\end{array}$ & $\begin{array}{l}\text { No with anti-dengue } \\
\text { virus IgM }(\%)\end{array}$ \\
\hline Trading & $22(23.7)$ & $1(4.5)$ \\
Farming & $21(22.9)$ & $4(19.0)$ \\
Civil servants & $19(20.4)$ & $5(26.3)$ \\
Students & $18(19.4)$ & $4(22.2)$ \\
Artisans & $13(13.9)$ & $2(15.4)$ \\
Total $(\%)$ & $93(100)$ & $16(17.2)$ \\
\hline
\end{tabular}

Table 4. Geographical distribution of anti-dengue virus IgM antibodies in Ogbomoso

\begin{tabular}{lll}
\hline $\begin{array}{l}\text { Geographical } \\
\text { distribution }\end{array}$ & $\begin{array}{l}\text { No Tested } \\
(\%)\end{array}$ & $\begin{array}{l}\text { No with anti-dengue } \\
\text { virus IgM }(\%)\end{array}$ \\
\hline Urban dwellers & $47(50.5)$ & $10(21.3)$ \\
Rural dwellers & $46(49.5)$ & $6(13.0)$ \\
Total $(\%)$ & $93(100)$ & $16(17.2)$ \\
\hline
\end{tabular}




\section{DISCUSSION}

Dengue has been reported in many parts of subSaharan Africa; it is underreported and under recognized in malaria endemic regions because greater than $70 \%$ of febrile illnesses are treated presumptively as malaria. There are also no proper medical examination and laboratory diagnosis for dengue virus in febrile illness person. Different studies have shown that dengue virus is actively circulating in various parts of Nigeria (Dawurung et al., 2010; Baba and Talle, 2011). This study is the first anti-Dengue IgM antibodies detection among healthy individuals in Ogbomoso. The prevalence rate of $17.2 \%$ from this study is lower than what Faneye et al. (2013) who reported 30.8\% among the population studied in Nigeria. Likewise it is also lower than that of Srinivas et al., (2013) who recorded $17.7 \%$ prevalence. Baba et al. (2009) reported $0.6 \%$ IgM seropositivity which is lower than the results from this study. In contrary the prevalence of dengue IgM from this study (17.2\%) is higher than that of Yew et al., (2009) that had $2.65 \%$ dengue IgM in the study carried out in Singapore. A high anti-Dengue IgM antibody was documented among the age range $0-15$ years $(28.6 \%)$, which was in line with Garg et al., (2011) that recorded $35 \%$ among the same age group in their study. This could be due to outdoor activities carried out by this age group and thereby expose to mosquitoes bites. The results show that dengue is a pediatric health problem considering the prevalence among age group of 0-15 years, which has also been reported by several international studies (Shah et al., 2006; Anderson et al., 2007). Females had $16.1 \%$ seroprevalence compare to that of male which is $18.9 \%$ and agrees with (Brown et al., 2009) who reported a statistical association of prevalence between males and females respectively as $9.55 \%$ and $0 \%$. In some previous study, the higher prevalence of dengue infection was also noted among males than females (Gupta et al., 2005; Ukey et al., 2010; Kumar et al., 2010). Civil servants and urban dwellers had $26.3 \%$ and $21.3 \%$ seroprevalence respectively. The prevalence rate in the urban (21.3\%) is higher than that of rural (13.0\%). This could be as a result of poor urbanization planning which allow more breeding sites for mosquitoes. Industrialization could also play an important role in the vector management control and enhance the spread of the virus in the urban area. Detection of dengue IgM antibodies should be available at our health centers so that proper diagnosis can be made early and vector control should be of great importance so far there is no vaccine available at present. It is therefore encourage to carry out molecular epidemiological survey for the virus in future.

\section{REFERENCES}

Anderson, K.B., S. Chunsutiwwat, A. Nisalak, P. Mameen and D. Libarty et al., 2007. Burden of symptomatic dengue infection in children at primary school in Thailand: A prospective study. Lancet, 369: 1452-59. DOI: 10.1016/S0140-6736(07)60671-0

Baba, M.M., M.F. Sharon, A.V. Vorndam, J.A. Adeniji and O. Diop, 2009. Dengue virus infections in patients suspected of malaria/thyphoid in Nigeria. J. Am. Sci., 5: 129-134.

Baba, M.M. and M. Talle, 2011. The effect of climate on dengue virus infection in Nigeria. New York Sci. J., 4: 28-33.

Brown, M.G., I.E. Vickers R.A. Salas and M.F. Smikie, 2009. Seroprevalence of dengue virus antibodies in healthy Jamaicans. Human Antibodies, 18: 124-6. DOI: 10.3233/HAB-2009-0207

Chamber, T.J., C.S. Hahn, R. Galler and C.M. Rice, 1990. Flavivirus genome, organization, expression and replication. Annual Rev. Microbiol., 44: 649-688. PMID: 2174669

Dawurung, J.S., M.M. Baba, G. Stephen, S.C Jonas and D.N. Bukbuk, 2010. Serological evidence of acute Dengue virus infection among febrile patients attending, Plateau State specialist hospital Jos, Nigeria. Rep. Opin, 2: 71-76.

Faneye, A. N. Idika, B.O. Motayo, A. Adesanmi and E. Afocha, 2013. Serological evidence of recent dengue virus infection among febrile children in a semi arid zone. Am. J. Infect. Dis., 9: 7-10.

Garg, A., J. Garg, K. Raoy, G.C. Upadhyay and S. Sakhuja, 2011. Prevalence of dengue among clinically suspected febrile episodes at a teaching hospital in North India. I. Infect. Dis. Immun., 3: 8589.

Gulber, D.J., 2010. Dengue Viruses: In: Desk Encyclopedia of Human and Medical Virology, Mahy, B.W.J. and M.H.V. Van Regenmortel, (Eds.),, Academic Press, Oxford, ISBN-10: 0123785596.

Gupta, E., L. Dar, P. Narang, V.K. Srivastava and S. Broor, 2005. Serodiagnosis of dengue during an outbreak at a tertiary care hospital in Delhi. Ind. J. Med. Res., 121: 36-38. PMID: 15713977 
Kumar, A., C.R. Rao, V. Pandit, S. Shetty and C. Bamigalti et al., 2010. Clinical manifestations and trend of dengue cases admitted in a tertiary care hospital, Udupi, Karnataka. Ind. J. Comm. Med., 35: 386-391. DOI: 10.4103/0970-0218.69253

Shah, G.S., S. Islam and B.K. Das, 2006. Clinical and laboratory profile of dengue infection in children. Kathmandu Univ. Med. J., 13: 40-4. PMID: 18603866

Srinivas, R.M., S., Pavani K.M. Dass, M.A. Kareem and E.V. Vinayaraj, 2013. Seroprevalence of dengue virus in a tertiary care hospital, andhra Pradesh, South India. Int. J. Res. Med. Sci., 1: 448-450. DOI: 10.5455/2320-6012.ijrms20131127
Ukey, P.M., S.A. Bondade, P.V. Paunipagar, R.M. Powar and S.L. Akulwar, 2010. Study of seroprevalence of dengue fever in central India. Ind. J. Comm. Med., 35: 517-519. DOI: 10.4103/09700218.74366

Weaver, S.C. and W.K. Reisen, 2010. Present and future arboviral threats. Antiviral Res., 85: 328-345. DOI: 10.1016/j.antiviral.2009.10.008

Yew, Y.W., T. Ye, L.W. Ang, L.C. Ng and G. Yap et al., 2009. Seroepidemiology of dengue virus infection among adults in Singapore. Ann. Acad. Med. Singapore, 38: 667-675. PMID: 19736569 